\title{
4. Democratic Ambivalence? Ministerial attitudes to party and parliamentary scrutiny
}

\author{
James Walter
}

\section{Introduction}

This chapter draws upon research into the working lives of a particular cohort of Australian federal politicians - those elected on 10 December 1977. ${ }^{1}$ They were interviewed twice in 1978 - on arrival in Canberra and again at the end of that year-for a monograph on their experience of acculturation to parliament and to representative politics (Walter 1979). All but two were interviewed again between 2005 and 2009 when their parliamentary careers were over. The sequence provides an unusual opportunity for longitudinal comparison of attitudes, aspirations and beliefs of a cohort at the beginning of their political careers, and again in retrospect as they look back on their achievements. ${ }^{2}$

Not all of the new parliamentarians of 1977 participated in the initial study; of the 27 new backbenchers that year, ${ }^{3}$ four were excluded because of past federal parliamentary experience and one refused to participate. When it came to the follow-up interviews about 30 years later, of the initial group of 22, one (former Senator Janine Haines) was deceased and one (former Senator Allan Rocher) could not be located. The resulting subject group (now numbering 20, and all male) was as shown in Table 4.1.

In following the fortunes of a single cohort, we are reminded of the contingencies of politics. It is not a 'representative' group that can be drawn upon for statistical purposes, but rather one whose membership is entirely fortuitous. Yet its collective biography gives us a snapshot of the experience of politics at a historically important juncture in Australian history, as the policy regime that had prevailed since the late 1940s faltered and a new orthodoxy was ascendant.

\footnotetext{
1 The longest-serving member of the cohort, Senator John Watson, completed his final term in Parliament at the 2007 federal election.

2 Recent research was funded by an Australian Research Council Discovery Grant, 2005-2007 [DP0557983]. The transcripts of the original 1978 interviews are held in the National Library: see James Walter, Papers 1976-1986, NLA MS 7846.

3 There were 24 elected on 10 December 1977-14 MHRs and 10 senators - with two senators appointed during the course of the year and one further MHR joining as the result of a by-election.
} 
Although there was roughly equal representation of the major political parties within the cohort, the experiences of the party subgroups were to be significantly different. The nine Liberals, entering Parliament at a point when their party had almost repeated the landslide it achieved under Malcolm Fraser in 1975, could scarcely have expected that their opportunities to make a mark in government were limited: only one of their number (Jim Carlton) would achieve ministerial status before 1983; none would sit in cabinet; ${ }^{4}$ and only two would survive the long years of Labor's hegemony (1983-96) to experience the return of Coalition government under John Howard - and neither of these would attain a high profile in the Howard years.

The Labor members, on the other hand, were to reap the benefit of a change in the political tide: nine out of 10 would gain ministerial appointments the exception was Senator Ron Elstob); seven would sit in cabinet (although three of these only briefly); but four (Gareth Evans, John Dawkins, Brian Howe and Neil Blewett) were more or less continuously in the Hawke and Keating cabinets, ${ }^{5}$ holding at different times such important portfolios - among othersas the treasury, finance, trade, attorney-general, foreign affairs and the deputy prime ministership. When assessing attitudes of this cohort to party and parliamentary scrutiny of executive government, then, one must acknowledge the disproportion in relative experience, with the Labor members having vastly more direct executive experience, and Liberals looking in from the outside. Yet what were their starting points?

\section{At the Beginning}

A series of broad generalisations was more or less true of the entire cohort in 1978. ${ }^{6}$ They acknowledged the importance of the legislative function and spoke in highly conventional terms of Parliament's significance as a forum, but they did not subscribe to the myth that real decisions were made in Parliament: 'the general governing of the country is really an executive-civil servant, or political executive-civil servant operation, and in most cases those are only marginally affected by what goes on in Parliament' (Labor MP). Important decisions were made within the building, but not in the public domain or through debate

\footnotetext{
4 Six would hold shadow ministries at various points in opposition, but only four appeared serious contenders.

5 Evans and Dawkins were in cabinet from the first; Howe and Blewett were initially in the outer ministry, with Howe first appointed to a cabinet post in December 1984, and Blewett in July 1987. Blewett and Dawkins resigned from Parliament in 1994, Howe in 1996 and Evans in 1999.

6 For more detailed elaboration of the points below, see Walter $(1979,21-31)$.
} 
in the public chambers. 'What happens in the House itself on the surface has less effect than what happens behind the scenes. But it happens within the institution of Parliament, nonetheless' (Liberal MP).

Whatever source [sparks a policy issue]...it then comes through the sifting process of public service activity, government backbench committee work, and then it goes into the legislative committee and into cabinet and then the party room... by the time it reaches the public eye in the House of Representatives, most of the battle's over. (Liberal MP)

The locus for influence was the party room, the possibility of scrutiny was primarily in party backbench committees, and the forum for decision was the executive.

Many ascribed importance to parliament's role in disseminating information, airing positions and facilitating opinion aggregation:

I don't believe that debate in Parliament has much effect on the other side, or on changing any of its policies and attitudes. I do however believe that there is a percolation effect on the general pattern of debate out to the community... and perhaps more importantly I think the things you say in the House, if you say them well enough or the speech is good enough in content, will be picked up. (Labor MP)

For one or two, Parliament's publicising potential was essential-'a bigger, better class-room than you've ever had before' (Labor MP). But in most cases, their actions were at odds with this assertion: they did not pay attention to what was said outside the party or committee room; they confessed to rarely listening to their backbench peers; few felt they gained significant information from parliamentary debate; and none felt that intervention in the chamber was effective as 'by the time it reaches parliament, you've heard it all before', and 'it became clear to me that unless you had got in and put your case to the minister before the subject had ever arisen there was little chance that you were going to have much of a say in the matter' (Liberal MP). In any case, Labor members were not the only ones bound by their caucus: regardless of party (and despite protestations by some Liberals that they would cross the floor if conscience demanded), the backbenchers - at least at this early stage of their careers - were realists who would limit dispute and contention to their own party committee or party room rather than the parliamentary chamber.

These views were not surprising: more experienced backbenchers at that time had put 'what we do in parliament' at the bottom of their list of functions (Ruddock 1978, 243); and contemporary surveys of parliamentarians in Britain and Italy showed that they also rated their institutions modestly (Putnam 1973). Nonetheless, for opposition backbenchers, this was immensely frustrating: 
I've never felt quite so peripheral or quite so marginal or quite so lacking in any influence over the course of what happened in something I've spent so many hours doing... Really just a question of sitting around a lot and listening to other people and...I don't find that an especially productive sort of an exercise. (Labor senator)

Even government backbenchers cavilled at the constraints on their capacity publicly to have an effect on anything:

The work up in parliament, it always had to be party demands to a large extent but you liked to feel that you had input... You worked to see that the area was covered and you put out a report that was worthwhile even if mostly they weren't read...it was...frustrating, but you realise that's part of the way things are done. (Liberal MP)

Predictably, then, there was a tendency to support parliamentary reform of the sort that would enhance parliamentary power in relation to the executive and, again, this was more or less general: 'one of the great weaknesses of our parliamentary system is that the Parliament itself does not play a greater role in relation to regular executive and civil service action than it does...I'd certainly like to see that strengthened' (Labor MP). Common themes were improved physical conditions and better facilities, improvement in the investigative function (particularly through a better committee system in the lower house), more opportunities for private members' business and general backbench participation, more staff, and removal of ministers from the Senate to make it a genuine house of review. There were some different emphases according to party affiliation: government backbenchers wanted stronger overview of the bureaucracy; opposition backbenchers advocated strengthening parliamentary oversight of the executive and more stringent application of processes to prevent 'ministerial waffle', abuse of Question Time and 'oppressive use of the gag'.

In reality, most were well aware that the executive held the legislative reins and because of stringent party discipline was able to control the legislature. Thus, the continual resort to the party room - only there could argument or dissent conceivably influence one's own frontbench colleagues: 'a backbencher can influence, or a group of backbenchers can influence, party decisions in the party room. I think that's probably the most significant influence [they can have]' (Labor MP). For opposition backbenchers there was something else at stake in parliamentary action: speeches there would not influence government policy but were seen as potentially swaying public opinion and changing attitudes:

In so far as one is trying to create ultimately a climate of public opinion which will bring your party, your views, to power, then the...debates 
and what you say, you hope, will have some effect. Key phrases sometimes get picked up, you find that organizations that are interested... have read your speech, and that creates dialogue. (Labor MP)

What did this mean for democratic accountability? In most cases, backbenchers saw themselves as primarily accountable to their party: they would not be in Parliament at all were it not for their party affiliation, and it was the party that would be held to account at the next election. Some, but not all, acknowledged a responsibility to their constituents; the view that 'my primary obligation is to the people who voted for me' (Liberal senator) was rare. And as for the transparency that would facilitate informed citizen judgment? Here, views were more varied, including an implication that a general understanding of party positions (parliament's educative function) rather than the detail of decisions was what counted, with a minority suggesting that since what really mattered happened outside parliamentary chambers, the operations of committees and even the party room should be opened to public scrutiny:

[O]ne of my main concerns is to try to exhibit to the public the sort of things that go on behind the scenes, the sort of debate and discussion that goes on in non-public places - in the party room, between members, or between members and ministers. The Australian public is not sufficiently aware of the hard work behind the scenes. (Liberal senator)

Views on this matter were also linked to attitudes to how constituents understood the political role. Some felt that, inevitably, the role was not understood:

It's my job as a representative...to be informed, and even the best informed of my constituents have very little idea of even that concept... It's also my job to have a view of my role that is more highly developed than others [except perhaps] political scientists or whoever in my electorate might have happened to study the subject...it's important for me to have a much more creative view about my role, which they may never understand. (Liberal MP)

Others, in contrast, saw their job as channelling the community: 'I think that [a backbencher]...can reflect the mood of the community more accurately than those who are in, say, the higher ranks, or in cabinet, because they are so much more out of touch.'

This sort of variability on the question of accountability encourages a deeper probing of responses on Parliament, the executive and indeed what the backbencher is there for. And here one can see the beginnings of differential patterns, a move away from what at first seemed common responses. The drivers seem to be the importance ascribed to policy activism, Parliament itself and 'the people' one represents. 


\section{Policy Activists}

Aspiring policy activists described their purposes directly, sometimes with great precision: 'What I would really like to see... is for this government to come to grips with a genuine, effective national science and technology policy for Australia' (Liberal senator). More broadly, they spoke of engaging with change:

I've always approached the question on the basis of being interested in changing the course of Australia's development, including the way we do things, the way we look after people, the way we appear to the rest of the world... The political process is just one way of influencing that... but...it's the way I think I'm better suited to. (Labor MP)

I'm ultimately more interested in policy than in political tactics...I'm myself in a safe seat and the role of a member in a safe seat is...to improve the quality of the policy decision. (Liberal MP)

They linked career advancement with their policy orientation: 'taking an intelligent interest in policy...[is] the best way of preparing yourself if you're given anything else to do, and also bringing yourself to the attention of those who might be making that decision' (Liberal MP). They were in little doubt what they were there for, and this linked to views of the role of government itself as the driver of development. Party was, for them, more important than Parliament in shaping government:

[Parliament] could control the executive if it wanted to. But it doesn't because...it can't because of the influence of the political parties. Now I don't see that as a bad thing, by the way. I think it's very much more important for government to be controlled by political parties than...by parliament itself. (Labor MP)

The order of effectiveness of control over the executive [is] one the party room, two the Senate, three the House of Representatives through its procedures, in that order. But I don't think control of the executive is as big a problem as control of the bureaucracy. (Liberal MP)

They rated executive direction highly: 'Complex problems are best resolved in the first instance by technocrats and bureaucrats at the administrative level, and by executive direction, in order to establish priorities and get programmes running' (Labor senator). Not surprisingly, then, they were less concerned with the 'encroachment' of the executive on Parliament, making such comments as: 'The executive is reasonably well controlled. In fact...they're controlled to the extent of destroying a lot of their potential initiative' (Liberal MP); and 'above all else [Parliament] is simply the institutional vehicle for determining who is 
the Executive at any given time' (Labor senator). And of course, this tied in with their ambitions: achieving a ministry was everything, since only then would direct engagement with policy deliberation be possible:

The prospect of being in Parliament as such has only got a reasonably limited appeal... But the whole point about Parliament of course is that being here is the precondition for being anything else...[I] would not put any time limit on reaching the ministry, but obviously that's where the real action is, and obviously that's where I'd ultimately like to be. (Labor senator)

I'm used to occupying positions of greater responsibility than I have now... and I don't think I'd be satisfied with staying on the backbench for ever. But I'd...expect to stay on the backbench for the length of this parliament because there are a hell of a lot of people in the queue. (Liberal MP)

Finally, one's obligation to the people was abstract and subordinate to other considerations:

[I]f there's a mistake which the Labor Party made in government it was that it tended to respond too quickly, and too generously, to the various demands of...interest groups...The government probably thought it could expect support from those groups, which wasn't always forthcoming...It would have been better for the government to say, well, we are the ones who are best able to interpret what to do in a community. We are not going to take all that much notice of you people, because you are not elected-we are...

[And later in this interview] Many people misconstrue what they would call the interest of their constituency. What they really mean is the view of those people who are most vocal and most influential in their constituency and I always tend to keep that in proportion...I would be...more interested in pursuing what was in the interest of the party in general rather than what the most influential people in the electorate were saying. (Labor MP)

In all cases, this group held safe seats.

\section{Parliamentarians}

A second subset could be designated parliamentarians. For them, even if decisions were made in domains not accessible to the public, Parliament remained important as a forum 
within which there can be public scrutiny of government - that's the first and major point as I see it. It's a forum in which opposition is formally recognized, which I think is absolutely the key to the democratic system...I think it's extremely important and effective in influencing events. Partly I suppose simply because of its tremendous propaganda power. (Labor senator)

Parliament can be one step ahead of public opinion, public demand. And I think that changes can be brought about through the parliamentary system...For a person who's psychologically disposed to being involved in public activities, the parliament is still the best place...If it's not parliament and one is going to operate in the public arena...I mean it's almost got to be parliament or the street. (Liberal senator)

Sharing the general view of the limitations of the institution, they nonetheless thought it could be improved, typically focusing on both changes to formal procedures and improvements to the committee system as means of enhancing legislative scrutiny and executive accountability. It was one of this number who thought transparency relating to what was decided in 'non-public' spaces a useful reform: 'some sort of public exhibition of how the place works is important' (Liberal senator). In most cases, there was reference to the hope of an executive role, but this was not, even at the outset, the sole criterion of success:

I suppose that anybody who wants to come into the parliament and didn't have the ambition to advance shouldn't be here, and he wouldn't have exhibited the sufficient ambition to come in the first place... The front bench is only another step forward. But I certainly won't see it as an example of mass failure or a matter of great frustration if I don't make the front bench. (Labor MP)

I don't see my Senate career in terms of a ministerial appointment... [or ministerial appointment as] the badge of success or failure of my career. (Liberal senator)

For the parliamentarians, however, what they did in Canberra, what could be done potentially on the national stage and 'for the country', rated more highly than what they did back in the constituency: 'Nobody here in federal parliament has a higher responsibility than his responsibility to the nation... And if the interests of his particular electorate are not coincidental with the interests of the nation...then he is in a very difficult position, but I think his responsibility is to the nation first' (Liberal senator). 


\section{Delegates ${ }^{7}$}

The final group can be designated delegates of the people. They might well be proactive: 'I think', said one, 'that you only put a point of view in the chamber [rather than really influencing policy]...I think that a Senator's work...is done in the electorate convincing a lot of people in the electorate. I think that you help to bring certain pressures on parliament by that work' (Labor senator). But more typical were views such as these:

I think essentially you're really trying to relate to your electorate...that is of primary importance... You have to let them know that you're active and doing the job as their representative... More broadly you do see your role as being part of a team, part of a decision making process... but that flows from the somewhat narrower start that I've just defined... The narrow start is the important one: you are elected by a certain number of electors in your electorate, and I think you have to satisfy them that you are doing their job for them. (Liberal MP)

You've got to be in your electorate assisting your constituents more so than here in Canberra...the main job of a politician the way I see it today is, being political, if you want to stay alive and stay in politics you've got to show that you're doing a job in your electorate...It's how you fire back in your electorate that makes you a good politician. (Labor MP)

Their executive aspirations were qualified:

I came in not with any particularly blue-eyed ideal, but pragmatically attempting to do a job, to contribute to doing a job to the best of my ability...There is no single goal or ambition that you can say I have, and I quite frankly don't understand anybody who does. (Liberal MP)

While advancement would be appreciated, their ambitions were not precisely articulated: 'I'll remain in parliament until I feel it's time for a change' (Liberal MP). They were critical, but had a realistic view, of executive power and did not expect reform to change this. In some cases they advanced principled views of their responsibility to the people, but for most it was conceived as necessity: 'I'll only stay there if I work hard and am a good member...There's a good chance of staying there if you work hard enough' (Liberal MP); 'Any politician who doesn't put his electorate first is mad. There's enough backstabbing and factional operations going on [in] any political party' (Labor MP). They were preoccupied with insecurity and with shoring up the home base - constituency responsibilities and local branch activity rated highly. Often it was for good

7 Here and throughout the chapter, I draw on one of the most familiar typologies of representation: the delegate/trustee distinction (see Eulau and Wahlke 1978; Sawer and Zappala 2001). 
reason - some (but, interestingly, not all) occupied marginal seats. Two of their number would be short term, but some would survive as long as the high achievers.

Where would the differential conceptions of these subsets of the 1977 cohort lead?

\section{Looking Back}

Looking at the career trajectories of our cohort, there was a remarkable congruence between the initial attitudes of the three subgroups and the degree of later political success. All of those whose attitudes fitted the pattern designated above as 'policy activist' achieved ministerial or shadow ministerial status. In hindsight, it is fitting now to reclassify these as 'executive/achievers'. Some of the 'parliamentarians' also reached the ministry or shadow ministry, although they were less likely to reach cabinet proper and were more ambivalent about executive experience. But those most trenchant about their parliamentary identity, or the value of the institution, usually reached only the margins of influence, though they sometimes offered cogent retrospective arguments about their political success - usually in terms very different from those used by the 'executive/achievers'. The third group, however - those who were constantly looking back to the constituency, who interpreted their role as 'delegate of the people' - would not reach the inner circle. David Riesman's (1950) distinction between inner and other-directed characters serves well to highlight the dynamic in play. The executive/achievers were inner directed, driven by their own sense of what mattered and acknowledging accountability only to their own conscience - which, said one, 'ought to be more demanding' than party, Parliament or electorate (Liberal minister). The delegates of the people were other directed, taking their cues from elsewhere, but, it was ruefully reflected, though they struggled to keep in touch and to reflect their community, 'the pressure from that direction wasn't great' (Liberal senator). How did these factors translate into retrospective attitudes to government and democracy?

\section{Executive/Achievers}

Most of the executive/achievers, reflecting on their experience, found confirmation of their initial views of the importance of executive direction and a relatively modest role for parliamentary scrutiny. Their views, in other words, had not changed as a result of experience: success had confirmed what they always knew, and to some extent their views had hardened. 'My expectation', said one, 'was from day one purely instrumental. It was all about winning 
government and then it was about using government...to do good policy things...I've only ever regarded parliament as a means to acquire the capacity to do things in executive government' (Cabinet minister 1).

I always felt that a lot of politicians were policy people and I always felt that I was a policy [person] - I mean I was never really interested in the parliament as such. I never felt I was going to become a parliamentarian, I felt I was there to do something else and the parliament was a means to that end. So I wouldn't ever think I achieved a great deal as a parliamentarian as such, but as a policy person I think I probably achieved some things, yes. (Cabinet minister 2)

They looked around them and saw that all who mattered were of the same ilk:

[O]ne of the things I think that struck me about the Keating and Hawke government was that the policy concerns they had were striking. I mean Evans, [John] Button, Don Grimes, Peter Walsh, Dawkins... A lot of them were very much driven by policy concerns and they wanted to make these sorts of changes, that's what drove them along. I doubt whether that was true of Hawke in the same way...he was very detached and he was a very good manager because of that detachment. But Keating... again, I would have said that most of my cabinet colleagues were in it primarily to bring about changes. That is not to neglect the fact that achieving those changes would be good for them (politically). (Cabinet minister 3)

The consequence was a fairly careful calibration of the prerogatives of the Parliament and the executive:

From my point of view the most important forum was not the parliament but the cabinet room. It is useful to be effective in parliament as well but it's not as important, when you're in government, as being effective in the cabinet room...

[And later] It's the executive that matters...[W] hat the New Zealanders have done is really very peculiar...[T]he theory of it was that you wanted parliament running the government, not the executive, but I think that's a nice theory but I don't think it works terribly well. What you lose in that is a kind of authority and an ability to get things done in difficult circumstances...I mean the parliament is useful for keeping the government honest and that's a key role...that level of accountability is very important in terms of preventing corrupt practices or having secret things going on...But the most important part of it is having a strong but nevertheless accountable executive. Not being pushed around by the parliament though too much! (Cabinet minister 4) 
Within the cabinet, however, it was not a competition of equals; the Expenditure Review Committee (ERC) was in the box seat: 'The policy agenda was determined largely by the ERC, not by the cabinet. The usual inner-party "democracy" there, the inner group' (Cabinet minister 2).

[By] the time I came to cabinet the ERC was really in charge of [the] funding of the government and that's where the arguments took place between the economic makers and occasionally poor characters like me hauled in to justify our heavy expenditures. But there's a lot of policy making there by the cabinet leadership...none of the major issues I was involved with was ever contested in the cabinet. It was really getting the money that was the issue, I mean; my toughest times were never in cabinet, they were always in the ERC. (Cabinet minister 3)

Cabinet colleagues loomed large, the party had to be considered, experts were attended to-but public opinion was of less interest:

I will be sensitive to the views of the chief colleagues in the government... Also I took general heed of the party, and especially of the [relevant] caucus...committee and I went out of my way to duchess people in that committee, keep them informed. The leading figures on that committee are the ones you knew had influence, because provided your stuff got through there you were unlikely to have any problems in caucus. So I think those two kinds of awareness were given a fairly high priority. I'm not sure I took much notice of public opinion...the other thing you pulled in, expert knowledge. I think I took a lot on from expert knowledge, if the experts convinced me. (Cabinet minister 3)

I was able for years to basically be indifferent to, to ignore the currents and the things that were running in the community...you just can't do that if you're in the Rep seat; you just have to be attuned to what people are saying. (Cabinet minister 1, Senate based)

Indeed, for the high-achiever circle, even the party came to be of less significance:

Hawke's usual [forays] into caucus I thought were pretty lacklustre because he never put the effort into caucus that he put into cabinet. He prepared himself superbly for cabinet, but you got the feeling that he never made that kind of effort with caucus except, as I say, when he was under pressure, and on the whole he had a very easy laid-back relationship with caucus. (Cabinet minister 3)

Yet there were some in the high-achiever group who were uneasy, who had some residual concern for what they were doing to Parliament: 
Well I think the executive gets more and more powerful and I think that was probably less so when I was first in parliament. I think there was the sense in which individual opinions counted much more...I think the whole show has become much narrower as the society has become much more complex and I think that's a huge worry in the long run. The executive became more and more powerful all the time and I think we're responsible for a lot of that. (Cabinet minister 2)

I would have thought that if you want to make a condemnation of the Hawke/Keating government it was their almost total failure of attention to constitutional parliamentary and party reform...The one thing the cabinet did to my amazement was that they killed off estimates committees in the lower house, which in opposition we in the lower house had enjoyed as one of the few places where backbenchers could have a go at the government, get to the public officials. But on the grounds of efficiency, one of the first acts of the Hawke government was that it was ended, on the grounds that it was being done well enough by the Senate. I think it was typical of their attitude, or our attitude I suppose, that those sorts of issues never got any real attention or enthusiasm from the government...I think the constitutional efforts we made were ham-fisted and poorly planned and I suspect not very enthusiastically supported by many members of the cabinet. (Cabinet minister 3)

One of these critics had shown an affinity with 'parliamentary' values in 1978 (though his 'policy activist' traits were pre-eminent); the other had always disavowed an interest in Parliament as such. Both critics in a sense represent figures moving towards the 'parliamentary' end of the spectrum as the oligarchic nature of their enterprise became more apparent. Yet, not surprisingly, while less fulsome than others of the inner circle (who would argue 'if you look at what are the basic parameters that give this country its institutional strength, its economic strength and such reputation as it has internationally just about every single element in the equation was a function of that period', Cabinet minister 1), they were pleased with what had been achieved, and proud to have been involved:

I felt in the '80s that it was a very strong government. I can't... believe I was there really, there were a lot of people with much more ability than I had. I felt that I was surrounded by people of some substance and arguments were very rigorous. That's why I had to learn to convert what I would regard as a moral argument into an argument that was much more empirical. (Cabinet minister 2) 


\section{Parliamentarians}

The self-descriptions of the parliamentarians may well be partially shaped by retrospective self-justification, but the interesting consistency between their initial views and where they ended up suggests an element of principle is also at work. They described themselves in 1978, and even more strongly in recent interviews, as parliamentarians first:

I suppose the central thing is you see...yourself in the role of a member of the parliament and I was...I've always been a life-long Liberal but I never saw my role primarily...I would never have put my party position...or my party feelings in a dominant role. (Liberal shadow minister 1, Senate)

I've been pretty much a person of the parliament. (Liberal senator, briefly Shadow minister 4)

They saw themselves as speaking for issues and ideas, the national interest, whatever the cost:

If you do [what I did], which is to try and speak the truth and to believe in something, and I believed in a number of things, not least relating to social justice and education let alone a whole lot of other things like shaping Australia, my priority was to work for them. Now, I'm not going to be made prime minister doing that...coming from that Liberal tradition where we speak the truth and I love it and I believe the people love it. The only people who don't love it is governments who want everyone to do what they say. (Liberal senator, briefly Shadow minister 5)

I see myself to some extent as a public intellectual and the result is... it's been a common element of simply raving on about things and trying to excite people about ideas or excite people about experiences. (Labor minister 3)

They held strong views about what could be achieved through Parliament:

[Y]ou achieve a lot of things that don't ever make the headlines. If you develop interests in various areas and you speak responsibly on them, not in parliamentary debates necessarily...But to work through the committee system and to talk in the party room, and you get up to speak about something and...people listen to you because you're respected and when policies come up and you go and talk to a minister or a shadow minister and say look there's some elements here that need development or you haven't thought about or could be done in a better 
way....and you're known to know what you're talking about, then you have an influence. But no one ever gives you a headline for that. (Liberal shadow minister 1, Senate)

What you learn is the art of waiting and building coalitions within the party room and across the chamber when you're in the minority in the Senate. And so whilst there may be some disappointment in not getting something this year or this session, your gaining credibility over time is just part of the art of politics, and the disappointment can sometimes be turned into quite a satisfying result. (Labor minister 2, Senate)

They did not evince the indifference towards electorate or constituency voices that was manifest among the executive/achievers:

[Constituency work is] very important in that it keeps you in touch with real people. It keeps your feet on the ground...It's a rarefied atmosphere. It's 'Yes, sir. No, sir. Three bags full, sir.' Cars and staff and offices and meals on tap, I mean it is a rarefied life... To go and judge [the] bestdressed bike competition at the local primary school fete, it keeps your feet on the ground, and to get to meet people and hear what they have to say and what their concerns are. (Liberal shadow minister 2)

Still, in keeping with their parliamentary preoccupation, they held to a trustee (rather than a delegate) view of representation: 'it's up to me to make a judgment at the time as to what I think [is] best. And if people don't agree with me, then they've got recourse to it later on' (Liberal shadow minister 1, Senate, speaking in 1978). Yet those who achieved ministerial office encountered the grind of satisfying cabinet, getting through the institutional process and yet pursuing their policy objectives:

[T] he toughest part about politics and in the...junior ministry...[is] that if you want to do something...you've got to take it through into cabinet and then...you have to take it through to the caucus committee and then you've got to take it through the caucus and then once that's all approved, then you've got to get it into the parliament... But the thing is you have to wait...Because you've got Treasury and basically all the senior ministers and, you know, money and all this sort of stuff, that's really important. So you might think, well you know, I'm the minister I'm not going to do all this, but it's very frustrating because you can't do it as quick as you'd like to be able to do it. (Labor minister 1)

In consequence, their views about what is was realistic to expect shifted - from idealism towards Realpolitik: 
[W] hen you get there you think, you know, I'm a member of parliament, I'm going to do what I can for the country and for the people in the electorate and all that sort of stuff and thanks very much for voting for me and I'm going to serve you and all that. And I did that to a pretty big degree but then...after you've been in there a while, it can't always happen like you thought it would happen. (Labor minister 1)

Typically, they came to think cynically that success depended on relations with the leader:

[B]eing friends of the leader is the first prerogative for advancement, if you're looking at success in terms of a ministerial appointment... I'd have defined success as someone who had a broad relationship with the community and was aware of the broad interests and was able to work to promote those interests through that career. (Liberal shadow minister 1 , Senate)

Those parliamentarians who became ministers or shadow ministers remained all too aware that key decisions were made in an inner circle to which they had not gained admission:

[D]ecision-making was very much top down and what would happen would be that decisions were made by the ERC, they'd then commit to cabinet, the cabinet will then commit to the ministry. And the ministry really just let the caucus then...tag along. Everything, all the decisive factors were contained in the budget... When the budget was presented to the caucus you might be looking at a process that only took ten minutes literally. Somebody would move, Keating would move the budget to be endorsed, yes, vote, bang and it was all over... The caucus debate was not significant... [As for the broader ministry] I remember the government had agreed on something which everyone was unhappy about, so I remember walking out with [Michael] Duffy and I said how did that happen? And he said well it's all a matter of numbers. He said there's three of them and there's only 24 of us. (Labor minister 3)

[I]n any party the legislation really flows out of the ministry and you're presented with it often at a stage where it's very late in the day and very hard to negotiate a change. (Liberal shadow minister 1, Senate)

They were also markedly more wary of the competition from colleagues than had been the executive/achievers (who acknowledged the battles but were not threatened by them).

[Maintaining good relations with caucus] is hugely important because if they're not happy with what you do and when you come up for the 
ministry again...someone will run against you if they're not happy with what you're doing... You know, because when you run into problems... they aspire...they take your job. And one thing...I told Kevin Rudd, I said, 'Now listen Kevin your mates of today can be enemies of tomorrow', you know. And I was meaning months on, because you're all aspiring. (Labor minister 1)

[Y]ou're sitting there at question time and the second question comes out of the blue to the fellow sitting next to you, Minister for $\mathrm{x}$, and you can immediately whiff the smell of an attack... and you think thank God it's not me and you sit there and whilst you feel some personal sympathy you're quite pleased that you are not the object of attack. And when the time comes when you are, you know they're thinking exactly the same...I mean to go from the caucus into the ministry is to achieve the reason why you went to the parliament and you're suddenly part of the elite group and there is a camaraderie, but if it means your fate as opposed to their fate then they prefer to see you swinging than themselves obviously. (Labor minister 2, Senate)

The real personal enmity is, I think, in the same side. It's not across the parties. You know that Winston Churchill story where the young member of the House of Commons is looking over and Churchill is on the front bench and this young fellow says, 'Oh look at the enemy', and Churchill turns around to him and says, 'No, my boy, that's not the enemy. That's just the opposition.' (Liberal shadow minister 2)

[T] here's a very large number of people in there, particularly, not only opposition, but a lot of people in your own side that are hoping that you can make a fool of yourself. It's actually not in their interests for you to do that well. (Liberal shadow minister 3, Senate)

Indeed, their experience encouraged not only an accommodation with Realpolitik in some cases (see above), but also a degree of bitterness as their party took a direction other than that for which they had signed on:

The point is that because government was doing all the driving, you see, the party had gone out of policy making. One of the issues I've talked about [is] policy anorexia...between 1986...or 1983 and 1996, the engines of policy generation were the cabinet and the bureaucracy. (Labor minister 3)

[T] he great swing from protected industries to the market forces, the user pays concept...I think has gone far too far now, it needs to be reevaluated...we were in the stage where we not only had huge tariff barriers but quotas as well, we did have inefficiencies [but]...I think we 
dismantled it all far too quickly. I think if we hadn't been driven by the ideal types in Treasury and Treasury really governs Australia. It doesn't matter what conceit parliamentarians have, Treasury have the whip hand and I think, you know, if we'd taken a more sober approach to [the] reform of the whole of the protection issue... a number of industries that disappeared and will never be re-established may well have adapted and survived...I think we went through a very unfortunate period in the Liberal Party with...I think it was that guy from West Australia, John [Hyde]...I don't think he had much background in economics, although that was his favourite topic, and he unfortunately introduced this wet and dry thing, which, I thought was enormously divisive and totally irrelevant too...it was a bowdlerised, patronised view of wets and dries. It was very uncomfortable and some of us had some pretty big fights about that. (Liberal shadow minister 1, Senate)

If the Liberal Party was soundly beaten, but I think it is going to take two beatings, they might reinvent themselves as a genuinely liberal party. (Liberal senator, briefly Shadow minister 5)

Yet they continued to salvage some sense of the importance of their contribution to the 'national conversation':

[T] he ex post facto satisfaction I get out of it would be to say that I never cease to be amazed by people I run into in the street or people I meet on a plane who said you've had a tremendous influence on my thinking, had a tremendous influence on me and I've never met you before, but I want to express gratitude. (Labor minister 3)

There's a hell of a lot of work in the parliament itself, as opposed to politics in general and somebody's got to do that work... And you have a number of backbenchers, not too many, but you've got a number who work very hard at those things and they never get any recognition, reward or acknowledgement for what they do. But they actually keep frying the fish. (Liberal shadow minister 1, Senate)

[K]eeping the Liberal Party within cooee of the public's sense of justice. I'd been helping to do that...[I] was constantly listening to the people I represented...but to some extent Australia...The whole debate in Australia, I would listen to it, participate in it and so it was fascinating. I loved it. It was much better than academic work. It was very real because the government does it or it doesn't do it, and when it doesn't do it eventually it catches up and they've got to do it. So I'm usually about three or five years ahead. (Liberal senator, briefly Shadow minister 5) 
Fred Chaney said, [I'm a] shining example, if a person specialises, [of] how you can really be effective as a backbencher...I've never been really [prominent], apart from [on] superannuation and tax and the accountability issues... and I've got much more satisfaction out of that than if I'm happily being a Minister of Veterans Affairs or Electoral Affairs or something like that. (Liberal senator, briefly Shadow minister 4)

\section{Delegates}

The third group - those who persisted in identifying as 'delegates of the people' - did not attain positions of influence. Thus, if their views developed, it was not as a result of executive experience. The contrast between their views and those of the high achievers is illuminating. More than the other two groups, they were overwhelmingly Coalition backbenchers, tempting the conclusion that their attitudes were a product of opposition, and of the attempt to understand their position, rather than experiential learning or persisting principle. And yet some of the Liberal cohort gained frontbench roles as shadow ministers and had clear affinities with executive/achievers or parliamentarians; the delegates did not. The consistency between their initial views and retrospection prompts the question: to what extent was their attention to the constituency an impediment to advancement in Canberra?

$[\mathrm{T}]$ he first and foremost thing in my opinion is not to neglect the people who put you there. You must maintain contact and listen to their problems...And I think the second thing is you use common sense and balance. And don't think you were born to be king, you just do the best you can...[T] he constituency was number one for me...I enjoyed getting around. It was a bit of a pain having to do it but once you got out there and started meeting people it was great, and they appreciated it. (Liberal MP 1)

The emphasis on commonsense, balance and not thinking you were born to be king (this last in marked contrast with the executive/achievers) recurs. Others would explicitly eschew ambition:

Most of us in my experience were in there doing a job, which we felt had to be done. To a great or lesser degree we did it to the best of our abilities. There were those who were as well motivated by a very rich ambition, which I didn't have. I had some ambition but I certainly wasn't in there to feather my nest or to further my career as it were, I was just happy to stay along and do the best I could. (Liberal MP 2) 
It is interesting, briefly, to review their views on policy processes and executive government. For them, party and committee work remained important: 'the backbenchers can play a role and they do play a role. Well they serve on committees and that sort of thing and they bring that up into the caucus, all their ideas and that sort of thing' (Labor senator). While some were convinced they had an impact through such means, others did not evince great confidence in the traction gained:

I did a fair bit of work on the backbench committee for industry. I remember I was part with Jim Carlton actually of a group who were lobbying for lower tariffs, that was one of our things at one stage. But I can't sit here and now and say here because of that something happened. It was just part of the mix of ideas and debate that was going on at a party level. (Liberal MP 2)

The backbench committee often was the outlet if you were involved with any of the backbench committees. If you could put your case hard enough, maybe the leader of that committee would take it up strongly with the minister involved and occasionally the ministers used to come down and talk to the backbench committees and I think you could get a little bit, but as I said at the beginning I felt that if you didn't get to these ministers before they had spoken, your chances of getting it... they didn't like to ever go back and...change their mind. It's very hard to do that, very hard to get them to change. (Liberal MP 3)

They maintained a realist view of the executive:

I think the executive has always been dominant...you've got to have a group of people who will sit down and work out policy and present the policy and then if you agree with them you go with them, if you don't you don't. You can't have policy-making formulation with...70 or 80 people who are quite convinced that they were born to be prime minister... you'd get nowhere. So that's why you have executive government and I think it's the only way to make the democracy work. (Liberal MP 1)

In several cases, their view of what it took to gain executive appointment emphasised contingency rather than merit:

[B]ecoming a minister is not an easy thing...I don't know, but it depends on the state you come from and then the number of contenders in the party in that state and the balance between Senate and House of Reps, because there's got to be some Reps and some Senate. The easiest way to become a minister in a coalition government is to be a member of the 
National Party from a state that has few representatives in the National Party, and have ability, some ability anyway, you don't have to be brilliant. (Liberal MP 1)

It was understandable that, while reiterating their commitment to matters of concern to their own electorate, some would rate their role in modest terms:

[A]part from particular issues of concern to their own electorates I'm not sure just how important in the general run of things is the contribution the members make in the party room etc, etc, etc. I don't know about that. Because I have a feeling often that on many issues the executive already has its expert advice from its own departments and officials and no matter what we say this is the way we're going to go. Such and such is the way we're going to go. So I'm not sure about that. It is important I think that both through committee work and in the party room points of view are made known and stands are taken and I think that is important and to that extent, yes, we have a role, backbenchers have a role. But is it any better a role than being a foot soldier? (Liberal MP 2)

Others, however, felt they had been effective:

I came here with no pretensions to lead the country or to be a minister, just to represent people, and so while a lot of people might say, 'Well, you've been here 27 years and not being a minister in government', you know, 'it's all very well to say you've been in opposition,' or been on the executive opposition, but during those years, I achieved quite a lot in terms of amendments...So, it's been very satisfying... And I've really been able to stand up for causes. (Liberal senator 1)

[I]t would have been nice to have achieved a ministry somewhere along the line but I wasn't there long enough to get there. Otherwise, no I was happy with what I was doing. I served on one parliamentary committee... and that was very interesting. Backbench work was interesting. (Liberal MP 2)

[Y]ou've got to have pin prickers. You know, populist ministers, even leaders of any party, you've got to pin prick it because they're full of balloons...all these guys, they have got to be reminded when they go outside their credibility area. (Liberal senator 2)

\section{Conclusion}

When this cohort entered Parliament it appeared at first glance that there were common attitudes: election was as a party representative, so accountability 
was primarily to the party; significant decisions were not reached in the public chambers of Parliament, but happened within the building and could be influenced by backbench activity in the party room and in committees; Parliament was a useful forum for influencing the climate of public opinion through the 'percolation effect' of debate; there should be reform to increase parliamentary efficiency and to enhance the power of Parliament in relation to the executive. Yet closer examination showed that even then there were different emphases within the cohort, patterns that would subsequently correlate with success in gaining executive appointment.

One group - the policy activists - had significant 'big picture' aspirations to affect the course of Australian development; couched their objectives in policy terms; spoke of their ambitions wholly in terms of attaining a cabinet position (as the way to put policy into effect); believed it was the role of the party rather than Parliament to control the executive; rated executive direction highly (and was not overly concerned about executive 'encroachment' on Parliament); and was comparatively indifferent to public opinion. This group was to be the most successful: they were to be the executive/achievers of their day. Its members' views changed little as a result of experience. Rather, on looking back, their instrumental approach to Parliament was confirmed; they measured success in terms of policy outcomes; they acknowledged accountability to Parliament and to the public, but were led to a careful calibration of parliamentary power in relation to the executive - 'Not being pushed around by parliament too much'; and, in a descending hierarchy of importance (the ERC, then cabinet, then party), public opinion came last. Yet some of their number showed a residual concern for the adverse effects of what they had done to Parliament and its processes; these had spun out from the centre towards the parliamentarians.

The second group - the parliamentarians - had set out with the conviction that Parliament's importance was underrated; it was a means of promoting 'the national conversation' and in this its members could be one step ahead of public opinion. This group saw the improvement of parliamentary processes to enhance the quality of legislation and to enhance executive accountability as important. Its members did not see gaining a ministerial role as a necessary measure of success, and had a trustee interpretation of their representative role (they would do what was best for 'the nation' rather than a particular electorate). Some of them would attain ministerial/frontbench roles, a couple even entering cabinet, but none would reach the inner circle. Looking back, they persisted in rating their parliamentary role as more important than party affiliation, arguing that what had been achieved often depended on work behind the scenes through parliamentary processes and 'building coalitions' across Parliament. They admired those who had been prepared to speak out, whatever the cost. They were critical of inner-circle decision making and often frustrated by more powerful 
'executive achievers' in pursuing their objectives. But they had tempered their idealism - 'it can't always happen like you thought it would happen' — and it was this group which had modified its views of ministerial/frontbench roles, with a Realpolitik interpretation of what was needed to succeed. In tandem, they expressed higher levels of insecurity than had the executive/achieversthere was always someone out to get your job, since 'you're all aspiring'. A few, from both parties, ended with bitter reflections on party change, but most confirmed a sense of satisfaction with what they had managed to contribute to 'the national conversation'.

The tailenders were the delegates. They set out believing that their task was to 'do a job for the electorate' and that initially they should concentrate on addressing the problems of their constituents rather than the work in Canberra. They were hesitant about articulating objectives and ambivalent about ambition. The best qualities were 'balance', 'commonsense' and not believing 'you were born to be king'. None would reach the front bench. A couple of them were to be shorttermers, battling in marginal seats, but some remained in Parliament for lengthy terms. And these still spoke in the end of 'the first and foremost thing' being 'not to neglect the people who put you there'. Modest in their own ambitions, they emphasised the importance of being guardians of the people's interests and pin-prickers of the inflated egos of their more ambitious peers - '70 or 80 people who are quite convinced that they were born to be prime minister'. Some would argue in detail about how effective they had been, most would attest to some satisfaction in the role, but one gave voice to what one suspects was a more common conclusion: 'is it any better a role than being a foot soldier?'

The self-belief of the executive achievers was remarkable: they were inner directed, driven by their own sense of what mattered, and acknowledging accountability only to their own conscience. They did not disavow ambition and were always intent on policy impact, more dismissive of parliamentary constraint and less attentive to public opinion (which was there to be shaped rather than responded to) than those of their peers who identified themselves as either what I have called 'parliamentarians' or 'delegates of the people'. One is drawn to the conclusion that they were 'intent on pushing and pulling the world into shape, forcing us to take notice of [them] whether we like it or not... [giving] us the big picture, its size and splendour presumably a measure of the [men] who put it in place' ${ }^{8}$ They had not come to an accommodation with 'the iron law of oligarchy' (Michels 1911) through experience; a belief in the necessity of political elites was where they started: 'we are the ones who are best able to interpret what to do in a community.' It is a position with a long history: in Australia, the need for steering by an elite political class had been vigorously argued by 'new liberals' from early in the twentieth century (see Walter and

8 I am paraphrasing Little $(1997,25)$ here - he was speaking of Paul Keating. 
Moore 2002). Arguably, it is an attitude of ambivalence towards democracy, if by democracy is meant a concern for dispersed leadership, institutional checks and balances, respect for institutional norms and public responsiveness. Yet those who were more attentive to the conventional indicators of democratic accountability, their institutional obligations and their representative rolesthe parliamentarians and the delegates - were the ones disadvantaged in the competition for influence. In fact the parliamentarians, at least those who gained the front bench, were the ones who were obliged to temper their idealismto accept a sort of oligarchic incorporation - in the interests of gaining policy traction.

Can we draw any conclusions about contemporary politics from a cohort whose service, in the main, spanned 20 years from 1977 until the late 1990s? If one compares the attitudes of this group with political biographies from earlier periods (Walter 2009), though this can hardly be conclusive, one's impression is that the ambition of the policy activists is perhaps more overt than was evident among earlier generations; is this a cultural shift, or were politicians of the past more willing to remain parliamentarians or delegates, less driven to 'change the course of Australia's development'?

On the other hand, comparing this cohort with subsequent generations provokes three observations. First, there has been a 'younging' (Weller and Fraser 1987) and professionalising (Jones 2003) of politics in succeeding cohorts. While the embourgeoisement of the political elite was certainly evident by the late 1970s (Encel 1981; McAllister 1992, Ch. 9), this was a group that was still more occupationally diverse than those who were to follow (for details, see Jones 2003; Pickering 1998; Walter 1979; and compare Weller and Fraser 1987). Second, the corollary is that this cohort had, with only one exception, taken up politics following an earlier career (or careers). Not for them the route of employment in a politician's office, or within the party organisation or a party-affiliated entity, which has increasingly characterised the novice politicians of the late twentieth and early twenty-first centuries. This group therefore had both life experience and work skills (including, in some instances, substantial administrative experience) that would stand them in good stead in governance, and that may be less common in those whose lives have been given entirely to politics as a first career. The extent to which this may have engendered different attitudes is yet to be explored. One might hypothesise that with professionalisation there has been yet further skewing towards activists and away from parliamentarians and delegates. Who, then, is to sustain sufficient of the parliamentarian's scepticism about the ' 70 or 80 people who are quite convinced they were born to be prime minister' to demand reality checks?

These observations notwithstanding, it is not my intention to lament the 'undemocratic' nature of the policy innovators of the past 20 years or the activists 
of the present. While, as I have argued elsewhere, they may sometimes go 'too far' (Walter 2005, 2008; Walter and Strangio 2007), we cannot prosper without their drive, imagination and innovation. I suspect that in the long term the range of character types drawn to politics is relatively unchanging; this cohort shows again that we are fated to see our circumstances dictated by people whose interest in policy change and 'power chances' trumps conventional concerns with democratic accountability. Political elites are inevitable; the task is not to attempt the futile enterprise of encouraging 'the democratic personality' (which, in this cohort, was most manifest amongst the parliamentarians and the delegates), but instead to build political frameworks that acknowledge policy activists as catalysts yet ensure 'democratic elitism' (Higley and Burton 2006) and decision processes that encourage 'deliberative democracy'. These are tasks for another day.

\section{References}

Encel, S. 1981. 'The Political Class: The Called and the Chosen'. In Class Inequality in Australia, ed. P. Hiller. Sydney: Harcourt Brace Jovanovich.

Eulau, H. and J. Wahlke. 1978. The Politics of Representation: Continuities in Theory and Research. Beverley Hills, Calif.: Sage.

Higley, J. and M. Burton. 2006. Elite Foundations of Liberal Democracy. Lanham, Mass.: Rowman \& Littlefield.

Jones, C. 2003. Working in Politics: Australian Parliamentarians and Professionalism. PhD Thesis, School of Social Sciences, La Trobe University, Melbourne.

Little, G. 1997. 'The Two Narcissisms: Comparing Hawke and Keating'. In Political Lives, ed. J. Brett, pp. 16-27. Sydney: Allen \& Unwin.

McAllister, I. 1992. Political Behaviour: Citizens, Parties and Elites in Australia. Melbourne: Longman Cheshire.

Michels, R. 1911 [1968]. Political Parties: A Sociological Study of the Oligarchical Tendencies of Modern Democracy. New York: Free Press.

Pickering, P. 1998. 'The Class of'96: A Biographical Analysis of New Government Members of the House of Representatives'. Australian Journal of Politics and History 44(1): 95-112.

Putnam, R. D. 1973. The Beliefs of Politicians: Ideology, Conflict, and Democracy in Britain and Italy. New Haven, Conn.: Yale University Press. 
Riesman, D. in collaboration with R. Denney and N. Glazer. 1950. The Lonely Crowd: A Study of the Changing American Character. New Haven, Conn.: Yale University Press.

Ruddock, P. 1978. 'Remarks'. Fourth Australian Parliamentary Seminar: Transcript of Proceedings, p. 243 ff. Canberra: Parliament of Australia.

Sawer, M. and G. Zappala (eds). 2001. Speaking for the People: Representation in Australian Politics. Melbourne: Melbourne University Press.

Walter, J. 1979. The Acculturation to Political Work: New Members of the Federal Backbench. Canberra: Australasian Political Studies Association and Parliament of Australia.

Walter, J. 2005. 'Why Prime Ministers Go Too Far'. In Australian Security after 9/11: New and Old Agendas, eds D. McDougall and P. Shearman, pp. 189-206. London: Ashgate.

Walter, J. 2008. 'Is There a Command Culture in Politics? The Canberra Case'. In Public Leadership: Perspectives and Practices, eds P. 't Hart and J. Uhr, pp. 189-201. Canberra: ANU E Press.

Walter, J. 2009. 'Political Biography'. In The Australian Study of Politics, ed. R. A. W. Rhodes, pp. 97-106. Basingstoke, UK: Palgrave Macmillan.

Walter, J. and T. Moore. 2002. The New Social Order? Australia's Contribution to 'New Liberal' Thinking in the Interwar Period. Presented to Jubilee Conference of the Australasian Political Studies Association, Australian National University, Canberra, 2-4 October.

Walter, J. and P. Strangio. 2007. No, Prime Minister: Reclaiming Politics from Leaders. Sydney: UNSW Press.

Weller, P. and S. Fraser. 1987. 'The Younging of Australian Politics or Politics as First Career'. Politics 22(2): 76-83. 